\title{
Nutrients decrease Al toxicity to resistant variety of wheat (Raj- 3077)
}

\author{
Archana Yadav \\ Biotechnology Division, Department of Zoology, Union Christian College, Aluva, Kerala
}

\begin{abstract}
Wheat is a second major staple food crop in south Asia after, rice. The wheat acreage to South Asia (India, Pakistan, Nepal, and Bangladesh) is more than 36 million hectare (FAO 2007). But it is also seems less to fulfill the needs of population. Different environmental factors and pollutants decrease its yield further. Aluminum decreases its root- shoot length and biomass at different concentrations; but nutrient supply decreases the toxic effects.
\end{abstract}

\section{Introduction}

Aluminum is found natural in soil, water, air (CEPA, 2000; ATSDR, 2006). Al ion contributes to soil acidity through their tendency to hydrolyze. The hydrogen ions released give a very low $\mathrm{pH}$ value in the soil solution and are a major source of hydrogen in most acid soils (Richard, 1998). Aluminum (Al) is toxic to plants at low $\mathrm{pH}$ and can begin to inhibit root growth within $3 \mathrm{~h}$ in solution experiments and finally decrease in yield. $\mathrm{Al}$ interferes with uptake or transport and utilization of essential nutrients like $\mathrm{Ca}, \mathrm{Mn}, \mathrm{P}, \mathrm{Mg}, \mathrm{B}, \mathrm{Fe}, \mathrm{Cu}, \mathrm{K}$, and Zn (Keltjens and Tan, 1993; Keltjens, 1995; Lukaszewski and Belvins, 1996; Slaski et al, 1996; Taylor et al, 1998; Lidon et al, 2000; Guo et al, 2003, 2007; Olivares et al, 2009).

\section{Material and method}

Plant Materials

Wheat (Triticum aestivum) Raj-3077 is an early maturity (115-120 days) medium height $(90 \mathrm{~cm})$ variety, released in Rajasthan, 1989 under wheat Breeding Scheme, RAU, ARS, Durgapura. It is resistant to brown and yellow rust, tolerant to Saline and alkaline conditions and well adapted to drought. Its grains are lustrous amber medium bold semi-hard with good chapatti making quality.

Seeds were surface sterilized with $0.1 \%$ mercuric chloride $\left(\mathrm{HgCl}_{2}\right)$. Equal sized seeds were sown at equal distance in Petri dishes lined with filter paper and germinated in dark at $25 \pm 5^{\circ}$ for $24 \mathrm{~h}$.

\section{Preparation of stock solution of Aluminum}

$1000 \mathrm{ppm}$ stock solution was prepared with Analar grade aluminum sulphate $\left(\mathrm{Al}_{2}\left(\mathrm{SO}_{4}\right)_{3} \cdot 16 \mathrm{H}_{2} \mathrm{O}\right)$. Various dilutions were prepared using distilled water and Hoagland's Solution respectively.

\section{Hoagland's' medium composition}

$\mathrm{KH}_{2} \mathrm{PO}_{4}, \mathrm{KNO}_{3}, \mathrm{MgSO}_{4} .7 \mathrm{H}_{2} \mathrm{O}$, Boric acid, $\mathrm{MnCl}_{2} . \mathrm{H}_{2} \mathrm{O}, \mathrm{ZnSO}_{4} \cdot 7 \mathrm{H}_{2} \mathrm{O}, \mathrm{CuSO}_{4} \cdot 5 \mathrm{H}_{2} \mathrm{O}$, Molybdic acid, Fe-EDTA make up to one liter of solution.

\section{Treatments for wheat}

Group A- Al solutions $(100,250,500,750,1000 \mathrm{ppm})$ made in distilled water; Group B- Al solutions $(100,250,500,750,1000 \mathrm{ppm})$ made in Hoagland's nutrient medium. Group A control was set in distilled water whereas of Group B in Hoagland's nutrient solution.

\section{Growth conditions}

The plants were grown under 500 watt fluorescent light bulb. This light stayed on for 10 hours a day for 10 days. Harvesting was after 10 days. Root numbers were counted while root-shoot lengths were measured with the help of scale. Roots and shoots were separated and oven dried at $60^{\circ} \mathrm{C}$ for two days. Dry weight was taken after two days on electronic balance.

Toxicity of different concentrations of Al on wheat

\section{Result}

Germination was recorded $95-100 \%$ at all concentrations i.e. no adverse effect on germination. Symptoms of toxicity were noted at high concentrations of $\mathrm{Al}$, reduced development of the roots, stubby appearance and were brownish color. Above ground portion of the plant, typical symptoms are small leaves, and shortened and thickened internodes 
There was dose dependent reduction in root number, shoot and root length and their dry weight, with the exception at $100 \mathrm{ppm}$ at which both shoot and root growth were least affected (Table 1). I found 100ppm Al concentration to be non toxic to seedlings. Rather it was favorable to shoot growth.

\section{Toxicity of different concentrations (diluent Hoagland's solution) on wheat}

There was no change in shoot number of wheat (T. aestivum) but root numbers were higher than control. Maximum (29.0\%) number of roots was found at $750 \mathrm{ppm}$.

Shoot length increased a little at 100ppm and 250ppm but decreased markedly at 750 and $1000 \mathrm{ppm}$ (Table. 2). The root length decreased gradually with increased $\mathrm{Al}$ concentration, with exception at $100 \mathrm{ppm}$ showing a little increase (14.5\%). The smallest roots were found in seedlings growing at $1000 \mathrm{ppm}$ (Table. 2).

Compared with control, both shoot and root dry weights increased at 100 and 250ppm but decreased at higher concentrations, being minimum at $1000 \mathrm{ppm}$ (Table 2). Similar trend was noted for total dry biomass of seedlings. R/S ratios declined at lower concentrations (100-500 ppm) but increased at higher concentrations (750-1000ppm).

Al toxicity was low when different dilutions of $\mathrm{Al}$ were made in Hoagland's medium suggesting plant nutrients in the medium provides protection to seedlings.

Table: 1 Toxicity of different concentrations of Al (diluted with distilled water) on wheat seedlings.

\begin{tabular}{|l|c|c|c|c|c|c|c|c|}
\hline & $\begin{array}{c}\text { Shoot } \\
\text { Number }\end{array}$ & $\begin{array}{c}\text { Root } \\
\text { Number }\end{array}$ & $\begin{array}{c}\text { Shoot } \\
\text { length } \\
(\mathbf{c m})\end{array}$ & $\begin{array}{c}\text { Root } \\
\text { Length } \\
(\mathbf{c m})\end{array}$ & $\begin{array}{c}\text { Dry } \\
\text { weight of } \\
\text { shoot } \\
(\mathbf{m g})\end{array}$ & $\begin{array}{c}\text { Dry } \\
\text { weight of } \\
\text { root } \\
(\mathbf{m g})\end{array}$ & $\begin{array}{c}\text { Total dry } \\
\text { weight } \\
\text { (mg) }\end{array}$ & $\begin{array}{c}\text { Root/Shoot } \\
\text { dry wt. } \\
\text { ratio }\end{array}$ \\
\hline Control & $1.0+0.0$ & $6.4 \pm 0.2$ & $13.2 \pm 0.7$ & $11.7 \pm 0.8$ & $11.7 \pm 0.8$ & $11.2 \pm 0.9$ & $22.9 \pm 0.9$ & 0.9 \\
\hline 100 & $1.0 \pm 0.0$ & $6.0 \pm 0.3$ & $15.6 \pm 0.7 *$ & $9.2 \pm 0.7$ & $14.1 \pm 1.1$ & $11.7 \pm 0.1$ & $25.8 \pm 1.9$ & 0.8 \\
ppm & $(\mathrm{Nil})$ & $(-6.3 \%)$ & $(+18.2 \%)$ & $(-21.4 \%)$ & $(+20.5 \%)$ & $(+4.5 \%)$ & $(+12.7 \%)$ & $(-15.6 \%)$ \\
\hline 250 & $1.0 \pm 0.0$ & $7.4 \pm 0.6$ & $11.9 \pm 1.3$ & $6.2 \pm 1.1 * *$ & $11.5 \pm 1.4$ & $9.9 \pm 0.6$ & $21.4 \pm 1.8$ & 0.9 \\
ppm & $(\mathrm{Nil})$ & $(+15.6 \%)$ & $(-12.1 \%)$ & $(-47.0 \%)$ & $(-1.7 \%)$ & $(-11.6 \%)$ & $(-6.6 \%)$ & $(-10.4 \%)$ \\
\hline 500 & $1.0 \pm 0.0$ & $7.2 \pm 0.4 *$ & $10.6 \pm 0.6$ & $5.3 \pm 0.4 * * *$ & $9.2 \pm 0.5 *$ & $8.4 \pm 0.6 * *$ & $17.7 \pm 0.7 * *$ & 0.9 \\
ppm & $(\mathrm{Nil})$ & $(+12.5 \%)$ & $(-19.7 \%)$ & $(-54.7 \%)$ & $(-21.4)$ & $(-25.0 \%)$ & $(-22.7 \%)$ & $(-6.3 \%)$ \\
\hline 750 & $1.0 \pm 0.0$ & $7.4 \pm 0.5$ & $1.7 \pm 0.04 * * *$ & $1.9 \pm 0.5 * *$ & $1.9 \pm 0.5 * *$ & $6.3 \pm 0.6 *$ & $8.3 \pm 0.9 * * *$ & 3.3 \\
ppm & $(\mathrm{Nil})$ & $(+15.6 \%)$ & $(-87.1 \%)$ & $(-83.8 \%)$ & $(-83.8 \%)$ & $(-43.8 \%)$ & $(-63.8 \%)$ & $(+243.8 \%)$ \\
\hline 1000 & $1.0 \pm 0.0$ & $7.2 \pm 0.5$ & $1.5 \pm 0.4 * * *$ & $1.9 \pm 0.7 * * *$ & $1.9 \pm 0.7 * * *$ & $5.8 \pm 0.8 * *$ & $7.8 \pm 1.4 * * *$ & 3.05 \\
ppm & $(\mathrm{Nil})$ & $(+12.5 \%)$ & $(-88.6 \%)$ & $(-83.8 \%)$ & $(-83.8 \%)$ & $(-48.2 \%)$ & $(-65.9 \%)$ & $(+217.7 \%)$ \\
\hline
\end{tabular}

$*$ Significance at $5 \% * * 1 \%$ and $* * * 0.1 \%$ probability, data in parenthesis indicate percent change in values in comparison to control

Table: 2 Toxicity of different concentrations of Al (diluted with Hoagland's solution) on wheat seedlings

\begin{tabular}{|l|c|c|c|c|c|c|c|c|}
\hline & $\begin{array}{c}\text { Shoot } \\
\text { Number }\end{array}$ & $\begin{array}{c}\text { Root } \\
\text { Number }\end{array}$ & $\begin{array}{c}\text { Shoot } \\
\text { length } \\
\text { (cm) }\end{array}$ & $\begin{array}{c}\text { Root } \\
\text { Length } \\
(\mathbf{c m})\end{array}$ & $\begin{array}{c}\text { Dry } \\
\text { weight of } \\
\text { shoot } \\
(\mathbf{m g})\end{array}$ & $\begin{array}{c}\text { Dry } \\
\text { weight of } \\
\text { root }(\mathbf{m g})\end{array}$ & $\begin{array}{c}\text { Total dry } \\
\text { weight } \\
(\mathbf{m g})\end{array}$ & $\begin{array}{c}\text { Root/Shoot } \\
\text { dry wt. } \\
\text { ratio }\end{array}$ \\
\hline Control & $1.0 \pm 0.0$ & $6.2 \pm 0.2$ & $10.1 \pm 0.4$ & $6.2 \pm 0.6$ & $10.1 \pm 0.7$ & $11.7 \pm 0.8$ & $21.8 \pm 0.9$ & 1.2 \\
\hline 100 & $1.0 \pm 0.0$ & $6.4 \pm 0.2$ & $10.5 \pm 0.3$ & $7.1 \pm 1.0$ & $10.7 \pm 0.9$ & $10.8 \pm 0.4$ & $21.5 \pm 1.1$ & 1.0 \\
ppm & & $(+3.2 \%)$ & $(+3.9 \%)$ & $(+14.5 \%)$ & $(+5.9 \%)$ & $(-7.7 \%)$ & $(-1.4 \%)$ & $(-12.9 \%)$ \\
\hline 250 & $1.0 \pm 0.0$ & $7.0 \pm 0.4$ & $10.9 \pm 1.2$ & $4.8 \pm 0.5$ & $11.2 \pm 1.4$ & $9.7 \pm 0.6$ & $20.8 \pm 1.7$ & 0.9 \\
ppm & & $(+12.9 \%)$ & $(+7.9 \%)$ & $(-22.6 \%)$ & $(+10.9 \%)$ & $(-17.1 \%)$ & $(-4.6 \%)$ & $(-25.0 \%)$ \\
\hline 500 & $1.0 \pm 0.0$ & $6.8 \pm 0.2$ & $10.1 \pm 1.7$ & $4.6 \pm 0.4$ & $9.5 \pm 1.7$ & $8.4 \pm 0.5$ & $17.8 \pm 1.6$ & 0.9 \\
ppm & & $(+9.7 \%)$ & $(\mathrm{Nil})$ & $(-25.8 \%)$ & $(-5.9 \%)$ & $(-28.2 \%)$ & $(-18.3 \%)$ & $(-24.1 \%)$ \\
\hline 750 & $1.0 \pm 0.0$ & $8.0 \pm 0.0^{* *}$ & $5.4 \pm 0.6^{* *}$ & $3.7 \pm 1.0^{*}$ & $4.5 \pm 0.5 * *$ & $6.8 \pm 0.4^{* *}$ & $11.3 \pm 0.6^{* *}$ & 1.5 \\
$\mathrm{ppm}$ & & $(29.0 \%)$ & $(-46.5 \%)$ & $(-40.3 \%)$ & $(-55.4 \%)$ & $(-41.9 \%)$ & $(-48.2 \%)$ & $(+30.2 \%)$ \\
\hline 1000 & $1.0 \pm 0.0$ & $7.4 \pm 0.5$ & $1.5 \pm 0.5 * *$ & $2.1 \pm 0 . .2 * *$ & $2.0 \pm 0.7 * *$ & $5.9 \pm 0.7 * *$ & $8.0 \pm 1.3^{* * *}$ & 2.9 \\
$\mathrm{ppm}$ & & $(+19.4 \%)$ & $(-85.1 \%)$ & $(-66.1 \%)$ & $(-80.2 \%)$ & $(-49.6 \%)$ & $(+63.3 \%)$ & $(+154.3 \%)$ \\
\hline
\end{tabular}

$*$ Significance at $5 \% * * 1 \%$ and $* * * 0.1 \%$ probability, data in parenthesis indicate percent change in values in comparison to control

\section{Discussion}

Aluminum exposure affected plant growth adversely. In the present investigation, $\mathrm{Al}$ stress decreased plant height, root length and plant biomass. These findings are in agreement with other workers (MossorPietraszewska, 2001; Ma, 2007; Zheng et al., 2007, Jiang et al., 2008; Diaz, 2011).

Wheat root and shoot growth were affected greatly in $\mathrm{Al}$ treatments $(250,500,750$ and 1000ppm) prepared after dilution of stock solution with distilled water (Table 1). Al toxicity at similar concentrations was relatively less 
when dilutions ( 250 and $500 \mathrm{ppm}$ ) of stock solution were made in Hoagland's nutrient (Table 2). This may be either on account of chelation of Al with EDTA or competition of Al with divalent cations for absorption. Bartlett and Riego (1972) reported same on maize seedlings.

The lower concentration of $\mathrm{Al}(100 \mathrm{ppm})$ had no adverse effects on wheat seedlings might be due to less Al was accumulated in tolerant wheat (Darko et al., 2004). Kochian (1995) reported that Al might be bound inactively to some component of the cell wall or cell membrane, or to ligands found in the cytoplasm or vacuoles.

\section{Conclusion}

The lower concentrations were not toxic to Raj-3077 resistant variety of wheat and dilutions made with Hoagland's nutrient medium supports seedling growth and decreased Al toxicity.

\section{Reference}

[1]. ATSDR, 2006. Draft toxicological profile for aluminum. Atlanta, US Department of Health and Human Services, Public Health Service, Agency for Toxic Substances and Disease Registry.

[2]. Bartlett, R. J. and Riego, D. C.1972. Effects of chelation on the toxicity of aluminum. Plant \& Soil 78: 79-84.

[3]. CEPA. 2000. State of the Science Report for Aluminum chloride, Aluminium nitrate, and Aluminium sulphate. Canadian Environmental Protection Act.

[4]. Darko, E., Ambrus, H., Banyai, E. S., Fodor, J. Bakos, F. and Barnabas, B. 2004. Aluminum toxicity, Al-tolerance and oxidative stress in an aluminum sensitive wheat genotype and in Al-tolerant lines developed by in vitro microspore selection. Plant Sci. 166: 583-591.

[5]. Diaz, D. R. 2011 Symptoms of aluminum toxicity of wheat on low-pH soils. AG Professonal magazine

[6]. FAO 2007. Statistical database http://www. fao-stat.fao.org

[7]. Guo, T.R., Zhang, G.P., Lu, W.Y., Wu, H.P., Wu, F.B., Chen, J.X. and Zhou, M.X., 2003. Effect of Al on dry matter accumulation and $\mathrm{Al}$ and nutrients in barleys differing in $\mathrm{Al}$ tolerance. Plant Nutri . Ferti. Sci. 9: 324-330.

[8]. Guo, T.R., Zhang, G.P., Zhou, M.X., Wu, F.B. and Chen, J.X., 2007. Influence of aluminum and cadmium stresses on mineral nutrition and root exudates in two barley cultivars. Pedosphere 17: 505-512.

[9]. Jiang, H.X., Chen, L.S., Zheng, J.G., Han, S., Tang, N. and Smith, B.R. 2008. Aluminum-induced effects on Photosystem II photochemistry in citrus leaves assessed by the chlorophyll a fluorescence transient. Tree Physiol. 28:1863-1871.

[10]. Keltjens, W.G. 1995. Magnesium uptake by Al-stressed maize plants with special emphasis on cation interactions at root exchange sites. Plant and Soil 171: 141-146.

[11]. Keltjens, W. G. and Tan, K. Z. 1993. Interactions between aluminum, magnesium and calcium with different monocotyledonous and dicotyledonous plant-species. Plant and Soil 156: 485-488.

[12]. Kochian, L. V. 1995. Cellular mechanisms of aluminum toxicity and resistance in plants. Ann. Rev. Plant Physiol. Plant Mol. Biol. 46: 237-260.

[13]. Lidon, F.C., Azinheira, H.G. and Barreiro, M.G., 2000. Aluminium toxicity in maize: biomass production and nutrient uptake and translocation. J. Plant Nutrition 23: 151-160.

[14]. Lukaszewski, K.M. and Blevins, D.G., 1996. Root growth inhibition in boron-deficient or aluminum-stressed squash may be a result of impaired ascorbate metabolism. Plant Physiology 112: 1135-1140.

[15]. Ma, J. F. 2007. Syndrome of aluminum toxicity and diversity of aluminum resistance in higher plants. Int. Review. Cytol. 264: 225252.

[16]. Mossor-Pietraszewska, T. 2001. Effect of aluminium on plant growth and metabolism. Acta Biochim Pol. 3: 673 - 686.

[17]. Olivares, E., Pena, E., Marcano, E., Mostacero, J., Aguiar, G., Benitez, M. and Rengifo, E. 2009. Aluminum accumulation and its relationship with mineral plant nutrients in 12 pteridophytes from Venezuela. Environmental and Experimental Botany 65: 132141.

[18]. Richard A. F. 1998. Soil pH: Natural resources conservation service. Agronomy Tech. Note No. 150.2.

[19]. Slaski, J.J., Zhang, G.C., Basu, U., Stephens, J.L. and Taylor, G.J. 1996. Aluminum resistance in wheat (Triticum aestivum) is associated with rapid, al-induced changes in activities of glucose-6-phosphate dehydrogenase and 6-pbosphogluconate dehydrogenase in root apices. Physiol. Planta. 98: 477-484.

[20]. Taylor, G.J., Blamey, F. and Edwards, D. G. 1998. Antagonistic and synergistic interactions between aluminum and manganese on growth of Vigna unguiculata at low ionic strength. Physiol. Planta. 104: 183-194.

[21]. Zheng, K., Pan, J. W., ye, L., Fu,Y., Peng, H. Z.,Wan, B. Y., Gu, Q., Bian, H. W., Han, N., Wang, J. H., Kang, B., Pan, J. H., Shao, H. H., Wang, W. Z. and Zhu, M. Y. 2007. Programmed cell death involved aluminum toxicity in yeast elevated by antiapoptotic members with decreased calcium signals. Plant Physiol. 143: 38-49. 